\title{
Kontakty naukowe polskich i rosyjskich matematyków w dwudziestoleciu międzywojennym
}

Zarys treści: Mimo nierzadko napiętych stosunków politycznych Polski i ZSRR, matematycy z obu krajów nie stronili od wzajemnych kontaktów. Polskie władze takich możliwości nie ograniczały, a radzieckie do połowy lat trzydziestych też nie czyniły tego w szerszym zakresie. Rosjanie pisywali do polskich czasopism, współpracowali z tutejszymi matematykami przy organizacji i prowadzeniu badań naukowych, gościli na polskich uczelniach jako wykładowcy i stypendyści, uczestniczyli w zjazdach tu organizowanych. Polskich matematyków również zapraszano z tych powodów na uczelnie ZSRR. Nierzadko nawzajem wspierano się także w kwestiach pozanaukowych.

Slowa kluczowe: relacje pomiędzy polskimi i rosyjskimi matematykami, współpraca naukowa, szkoły matematyczne.

Keywords: relations between Polish and Russian mathematicians, scientific collaboration, school of mathematics.

Współpraca naukowa polskich i rosyjskich matematyków miała tradycję sięgającą okresu przed 1918 r. W związku z tym mogła się intensywnie rozwijać już na początku lat dwudziestych, choć relacje państw, w których żyli, były trudne. Rosyjscy matematycy chętnie zamieszczali prace $\mathrm{w}$ wydawanym $\mathrm{w}$ Polsce czasopiśmie specjalistycznym o zasięgu międzynarodowym „Fundamenta Mathematicae” ${ }^{1}$, niemal od

1 „Fundamenta Mathematicae” były jednym z pierwszych czasopism matematycznych o wąskiej specjalizacji. W momencie ich tworzenia na świecie istniały głównie czasopisma poświęcone całej matematyce. Pomysł zakładania w Polsce periodyków o wąskiej specjalizacji pochodził od docenta Uniwersytetu we Lwowie - Zygmunta Janiszewskiego (Janiszewski 1918: 14-16). Pomysłodawca, od kwietnia 1919 r. profesor Uniwersytetu Warszawskiego (UW), nie zdołał zrealizować swej idei do końca, gdyż zmarł przedwcześnie w styczniu 1920 r., zanim ukazał się zebrany przez niego pierwszy tom periodyku. Został godnie zastąpiony przez nowych redaktorów, również profesorów UW Wacława Sierpińskiego i Stefana Mazurkiewicza. Periodyk był poświęcony teorii mnogości i dyscyplinom pokrewnym, drukował teksty w językach uznawanych w matematyce za międzynarodowe. Od 1920 do 1939 r. wydano 32 tomy czasopisma. Szybko odniosło ono znaczący sukces, stało się forum 
jego powstania w $1920 \mathrm{r}$. Stało się tak za sprawą przyjacielskich stosunków redaktora czasopisma, Wacława Sierpińskiego i jednego z najbardziej znanych w okresie międzywojennym rosyjskich matematyków Nikołaja N. Łuzina. Ich współpraca sięgała czasów przymusowego pobytu Sierpińskiego w Moskwie w latach 1915-1918. Po wybuchu I wojny światowej został on internowany na Białorusi, gdzie przebywał u krewnych żony; co prawda pochodził z Warszawy, ale pracował na Uniwersytecie we Lwowie, musiał więc przyjąć obywatelstwo austriackie ${ }^{2}$. Dzięki wstawiennictwu Dmitrija F. Jegorowa i Bolesława Młodziejowskiego ${ }^{3}$, profesorów matematyki z Uniwersytetu Moskiewskiego, pozwolono mu na opuszczenie Wiatki - miejsca internowania - i na pobyt w Moskwie (Mioduszewski 1998b: 69). Okres ten Sierpiński i Łuzin, który był uczniem Jegorowa, wykorzystali na wspólną pracę naukową, obaj interesowali się bowiem nowo tworzącym się wówczas działem matematyki teorią mnogości ${ }^{4}$. Istotna część późniejszego dorobku Sierpińskiego dotyczyła jej części zwanej teorią zbiorów analitycznych, a zainteresowanie tą tematyką zostało zapoczątkowane właśnie w okresie jego pobytu w Moskwie i współpracy z Łuzinem (Schinzel 1976: 41-43). Obaj byli też zwolennikami tworzenia szkół naukowych. W tym okresie świat naukowy zaczął już dostrzegać, że w wielu dyscyplinach daje to znacznie większe możliwości rozwoju i prezentacji osiągnięć niż ograniczanie się tylko do indywidualnej pracy uczonych, która jeszcze w XIX w. była przyjętym modelem działalności naukowej. W matematyce prężne szkoły funkcjonowały wówczas w Getyndze i Paryżu. W Moskwie Łuzin (w 1917 r. został profesorem) wraz z Jegorowem również zaczynał tworzyć szkołę. Grupa uczniów Łuzina w niedługim czasie stała się słynną w świecie matematycznym „Luzitanią”. Sierpiński zapoczątkował tworzenie szkoły matematycznej we Lwowie przed 1914 r. Po powrocie do Polski w $1918 \mathrm{r}$. z powodzeniem budował ją w Warszawie (Przeniosło 2011a: 32-35, 37).

Zarówno Nikołaj N. Łuzin, jak i jego uczniowie i współpracownicy pisywali do „Fundamenta Mathematicae”. Swoje prace zamieścili w tym periodyku: Paweł S. Aleksandrow, Andriej N. Kołmogorow, Dmitrij E. Mieńszow, Michaił J. Suslin, Paweł S. Urysohn, Aleksandr J. Chinczyn, Wiaczesław W. Stiepanow, Nina Bari, Michaił A. Ławrientiew i Piotr S. Nowikow. Tak znaczne zainteresowanie Rosjan czasopis-

prezentacji badań dla szerokiej rzeszy matematyków, zarówno polskich, jak i zagranicznych. Na temat tego periodyku zobacz (Przeniosło 2006: 167-184).

2 Lwowskie Państwowe Archiwum Obwodowe (LPAO), Uniwersytet Jana Kazimierza (UJK), f. 26, op. 5, spr. 1723, k. 49; Archiwum Akt Nowych w Warszawie (AAN), Ministerstwo Wyznań Religijnych i Oświecenia Publicznego (MWRiOP), sygn. 5618, k. 63.

3 Miał polskie pochodzenie.

4 Koniec XIX i początek XX wieku był to okres, gdy nadano już współczesny kształt podstawom tych działów matematyki, które od lat uprawiano w europejskich ośrodkach naukowych. W związku z tym zaczęto na szeroką skalę poszukiwać nowych pół badawczych. W matematyce działo się tak wiele, jak nigdy wcześniej, stawała się ona coraz obszerniejsza. Zwiastowało to rychłe nadejście czasów, w których nie będzie możliwe objęcie jej w całości na poziomie naukowym (do tej pory matematycy zazwyczaj zajmowali się całą dyscypliną) i w związku z tym nastąpi ścisła specjalizacja w uprawianiu różnych działów matematyki. Sierpiński i Łuzin należeli już do pokolenia „matematyków - specjalistów”. 
mem wynikało nie tylko z przyjacielskich stosunków Łuzina i Sierpińskiego, ale było także spowodowane dostępnością polskich periodyków matematycznych w ZSRR w okresie izolacji tamtejszej nauki na początku lat dwudziestych. Nie sprowadzano wówczas czasopism wychodzących w Europie Zachodniej i USA. W związku z tym rosyjscy matematycy mieli duże kłopoty ze śledzeniem nowych badań prowadzonych na świecie i tym samym z uniknięciem powielania już odkrytych faktów (Aleksandrow 1963: 176; Kuratowski 1973: 70). W takiej sytuacji Łuzin przysyłał Sierpińskiemu prace z prośbą nie tylko o ocenienie, ale i o stwierdzenie, czy nie pokrywają się w zbyt dużym stopniu z nowymi publikacjami, które ukazały się na świecie. Dotyczyło to np. tekstów Kołmogorowa, Mieńszowa, Suslina i Urysona, które opublikowano w tomie 4 czasopisma. Przyjacielskie kontakty Łuzina i Sierpińskiego sprawiły, że Redakcja starała się pomóc w opracowaniu tekstów i skonfrontowaniu z najnowszymi badaniami. W przypadku prac przeznaczonych do tomu 4 Sierpiński o opinię poprosił też jednego ze swoich uczniów, Kazimierza Kuratowskiego i lwowskiego profesora Hugona Steinhausa (Listy 2004: 150). Artykuł Suslina, który już wówczas nie żył (zmarł na tyfus w 1919 r.), został zredagowany przez Kuratowskiego.

Do warszawskiego czasopisma pisywali także rosyjscy matematycy pracujący poza ośrodkiem moskiewskim, również tacy, którzy osiągnęli później znaczącą pozycje naukową, np. z Leningradu - Leonid V. Kantorowicz ${ }^{5}$ i Grigorij M. Fichtenholz. Wśród prac autorów z ZSRR były teksty przełomowe dla różnych działów matematyki. Numery 7 i 8 zawierają na przykład kolejne części słynnego tekstu ${ }^{6}$ Pawła Urysona dotyczącego teorii wymiaru. W tomie 10 Nikołaj N. Łuzin przedstawił natomiast ustalenia kluczowe dla teorii zbiorów analitycznych ${ }^{7}$. W sumie w „Fundamenta Mathematicae” publikowało 30 Rosjan (głównie z Moskwy i Leningradu), co jest liczbą znaczącą, wszystkich autorów zagranicznych było 148 (z 19 państw). Większą grupę niż Rosjanie stanowili tylko autorzy z USA - 44. Matematycy z ZSRR zamieścili 61 prac na 311 opublikowanych przez obcokrajowców, najwięcej Łuzin, począwszy od tomu 2 wydrukował 8 tekstów i jeden jako współautor; Aleksandrow - 7 i 2 jako współautor i Uryson - 7 (Przeniosło 2006: 175, 176). Duża liczba publikacji autorów z ZSRR i fakt, że czasopismo było wydawane dzięki dotacji MWRiOP, świadczy niewątpliwie o tym, że polskie władze współpracy naukowej z matematykami z ZSRR nie ograniczały.

Sukces czasopisma i warszawskiej szkoły matematycznej niewątpliwie był konsekwencją skoncentrowania się na teorii mnogości i działach z nią związanych, głównie topologii (była domeną prof. Stefana Mazurkiewicza). Z perspektywy czasu wybór okazał się bardzo trafny, początkowo jednak te nowo tworzące się działy miały wśród matematyków równie wielu przeciwników, co zwolenników. Szczególnie dotyczyło to teorii mnogości, zarzucano jej nadmierną prostotę i możliwość uprawiania bez znajomości matematyki wyższej. W okresie międzywojennym do krytyków w pewnym

5 Laureat Nagrody Nobla z ekonomii w 1975 r.

6 Mémoire sur les multiplicités Cantoriennes. Został wydrukowany już po jego śmierci (utonął w czasie odpoczynku w Bretanii w 1924 r. podczas wspólnej z Aleksandrowem podróży naukowej po Europie, byli wówczas również w Warszawie).

7 Sur les ensembles analytiques. 
stopniu zaliczał się również Łuzin, mimo że od dość dawna interesował się tym działem matematyki i dużo publikował chociażby w „Fundamenta Mathematicae”. Nie był on jednak przeciwny zajmowaniu się teorią mnogości, ale nadmiernemu koncentrowaniu się na niej przez zbyt wielu matematyków, np. warszawskich. Dyskutował o tym z Wacławem Sierpińskim, był przy tym życzliwym krytykiem czasopisma i kierunków rozwoju polskiej matematyki. Po pobycie w Warszawie w $1926 \mathrm{r}$. bardzo szczegółowo przedstawił tę kwestię w liście do francuskiego matematyka, profesora Sorbony Arnauda Denjoy, który również znał wielu polskich naukowców, m.in. Sierpińskiego i - jak się można domyślać - interesował się kondycją tutejszej matematyki. Łuzin wskazywał na zagrożenie, które niesie ze sobą skoncentrowanie się zbyt wielu polskich matematyków na tak wąskiej problematyce, jaka mieści się w obszarze zainteresowań „Fundamenta Mathematicae”, czyli na teorii mnogości i działach pokrewnych. Uważał, że takie podejście może spowodować zdominowanie rodzimej matematyki przez te zagadnienia. Przytaczał również odpowiedź Sierpińskiego na te zarzuty - „Gdy powiedziałem p. Sierpińskiemu o rozmiarach niebezpieczeństwa, jakie przedstawia dominacja jednej drogi w ogóle, a teorii mnogości w szczególności, powiedział mi: »Tak, kryje się w tym poważne niebezpieczeństwo, lecz większym niż dominacja jednej tendencji jest brak jakiejkolwiek. Do czasu pojawienia się tendencji warszawskiej, matematyki w Polsce nie było, gdyż istnieli poszczególni uczeni, z których każdy interesował się różnymi rzeczami i którzy nie mieli uczniów [...]. Co się tyczy naszej ograniczoności, to mam nadzieję, że zmniejszy się ona, aż wreszcie zniknie «" (Łuzin 1983: 66, 67). Sierpiński traktował więc tę koncentrację jako początek drogi rozwoju polskiej matematyki i starał się przekonać o tym zarówno Łuzina, jak i innych matematyków wyrażających podobne wątpliwości. Z czasem krąg zainteresowań warszawskich matematyków rzeczywiście się poszerzał.

Wydaje się, że Łuzin przyjął argumenty Sierpińskiego, w liście do Arnauda Denjoy, oprócz przytoczonych wątpliwości, wskazywał na osobowość Sierpińskiego jako jedną z głównych przyczyn sukcesu warszawskiej szkoły matematycznej i „Fundamenta Mathematicae”. Tak pisał o nim: „P. Sierpiński jest znakomitym opiekunem naukowym. Stale pozostaje w ścisłym kontakcie ze swoimi uczniami, z którymi stosunki ma bardzo dobre i którzy go wyjątkowo cenią. Kieruje on ich ideami naukowymi, daje tematy prac, odważnie je publikuje i troszczy się o wszystko, nawet o sytuację materialną swoich uczniów" (Łuzin 1983: 67). Obserwacje te były bardzo trafne ${ }^{8}$. Sierpiński cenił zresztą Łuzina równie mocno, a wspomniane uwagi pod adresem szkoły niewątpliwie traktował jako konstruktywną krytykę. Za jego sprawą Łuzin otrzymał doktorat honorowy ${ }^{9}$ i w 1930 r. został członkiem czynnym Polskiej Akademii Umiejętności (Poczet 2006: 162).

8 Potwierdza je wiele źródeł: AAN, MWRiOP, sygn. 5510, k. 33, 34; Kuratowski 1981: 67, 78, 81; Schinzel 1976: 47, 48; Listy 2004: 147-149, 164; Ślebodziński 1971: 22; Przeniosło 2011b: 209-212.

9 Sierpiński wspomina o tym w liście do Arnauda Denjoy z 1936 r. Napisał w nim, iż Łuzin jest „jedynym sowieckim doktorem honoris causa polskiego uniwersytetu” (Duda 2004: 135). Jak się można domyślać, chodzi o UW, choć w spisie internetowym doktorów honorowych na stronach uczelni jego nazwisko nie widnieje. Wykaz doktoratów honoris causa UW od 1921 do 1939, uw.edu.pl, http:// 
Zagraniczni matematycy uczcili jubileusz „Fundamenta Mathematicae”, którym stało się wydrukowanie 25 tomów czasopisma, byli wśród nich również Rosjanie. Numer 25 ukazał się w 1935 r., miał podwójną objętość (liczył prawie 600 stron) i zaproszono do niego najbardziej znanych matematyków z całego świata. Spośród Rosjan swoje teksty zamieścili w nim wspomniani już Łuzin, Aleksandrow, Mieńszow i Nowikow oraz Abracham Besikowicz i Jakob D. Tamarkin. W związku z tym wydarzeniem Redakcja czasopisma otrzymała liczne gratulacje. Nadesłali je również rosyjscy matematycy, Kazimierz Kuratowski przytacza słowa pochodzące $\mathrm{z}$ listu Aleksandrowa, już od kilku lat profesora Uniwersytetu Moskiewskiego, który stwierdził, że jubileusz czasopisma jest świętem dla matematyków na cały świecie (Kuratowski 1963: 15, 16). W 1936 r. Jacob D. Tamarkin, pracujący jako profesor Uniwersytetu w Providence, opublikował w prestiżowym „Bulletin of the American Mathematical Society” bardzo pochlebny tekst mający uczcić ukazanie się 25 tomów warszawskiego periodyku. Napisał w nim m.in., że pod mistrzowskim kierownictwem „Fundamenta Mathematicae” szybko stały się niezwykłym czasopismem cieszącym się międzynarodowym uznaniem, którego historia jest też historią rozwoju nowoczesnej teorii funkcji i teorii zbiorów (Tamarkin 1936b: 300). Niewątpliwie przysporzyło to „Fundamenta Mathematicae” nie tylko splendoru, ale i nowych autorów.

Oprócz szkoły warszawskiej i „Fundamenta Mathematicae” Rosjanie współpracowali również z lwowskimi matematykami i tamtejszą szkołą stworzoną przez profesorów UJK Hugona Steinhausa i Stefana Banacha. Pisywali do założonego przez Steinhausa i Banacha kolejnego czasopisma specjalistycznego - „Studia Mathematica"10. Swoje teksty opublikowało w nim sześciu Rosjan z Moskwy, Leningradu i Odessy (m.in. Andriej N. Kołmogorow, Grigorij M. Fichtenholz i Leonid V. Kantorowicz) na 29 matematyków zagranicznych. Byli oni też autorami prac, które okazały się szczególnie ważne dla rozwoju dyscypliny, chociażby w tomie 5 ukazały się takie teksty Grigorija M. Fichtenholza i Leonida V. Kantorowicza ${ }^{11}$ oraz Andrieja N. Kołmogorowa ${ }^{12}$. Ten ostatni w swoim artykule w sposób twórczy odniósł się do książki Banacha Théorie des opérations linéaires ${ }^{13}$.

Nikołaj N. Łuzin analizował dość trafnie również sytuację w innych polskich ośrodkach akademickich, oprócz warszawskiego. Miał umiejętność całościowego

www.uw.edu.pl/o_uw/historia/dhcuw.html [dostęp 15.06.2013]. Akta uniwersyteckie w większości nie zachowały się, zestawienie może być więc niepełne. Łuzina nie ma także w podobnych spisach doktorów honorowych innych ówczesnych polskich uniwersytetów.

10 „Studia Mathematica” powstały w 1929 r. Podobnie jak „Fundamenta Mathematicae”, periodyk był poświęcony nowo tworzącemu się działowi matematyki - analizie funkcjonalnej i tym pokrewnym. Lwowskie czasopismo było też tak samo zorganizowane jak warszawskie i również ono w krótkim czasie zyskało uznanie w świecie matematycznym. Do 1939 r. wydano osiem tomów periodyku. Szerzej na temat czasopisma i szkoły lwowskiej zob. (Przeniosło 2007: 59-76).

11 Sur les opérations dans l'espace des fonctions bornées.

12 Zur Normierbarkeit eines allgemeinen topologischen linearen Raumes.

13 Była ona pozycją już wówczas cenioną w środowisku matematycznym, również przez Rosjan (Sobolew 1961: 263; Aleksandrow 1969: 61). 
spojrzenia, dobrze znał bowiem ówczesny świat matematyczny, gdyż dużo czasu spędzał za granicą. Lwowską szkołę matematyczną postrzegał podobnie jak warszawską. Z kolei Kraków uważał za ostoję matematyki klasycznej - tej od lat uprawianej w europejskich ośrodkach naukowych. Relacjonując Arnaudowi Denjoy swój pobyt w Polsce, oprócz przytoczonych już informacji i uwag, pisząc o niebezpieczeństwie zdominowania polskiej matematyki, sądził, że jest to tym bardziej prawdopodobne, iż sukces ośrodka warszawskiego i lwowskiego przyciąga młodych matematyków $\mathrm{z}$ innych miast, także $\mathrm{z}$ tradycyjnie przywiązanego do klasycznych działów matematyki Krakowa. Zwracał też uwagę na ostry konflikt między ośrodkiem warszawskim i krakowskim wynikający z osobistej niechęci liderów obu środowisk Wacława Sierpińskiego i najbardziej wpływowego z matematyków pracujących na Uniwersytecie Jagiellońskim (UJ) - prof. Stanisława Zaremby. Uważał, że animozje te stwarzają poważną trudność w szerszym uprawianiu w Polsce matematyki klasycznej. Podkreślał też, że na opuszczanie krakowskiego środowiska matematycznego przez niektórych tamtejszych młodych matematyków ma wpływ dość apodyktyczny charakter Stanisława Zaremby. Rozmawiał bowiem z osobami, które już wyjechały z Krakowa bądź nosiły się z takim zamiarem (Łuzin 1983: 66-68). Obserwacje te znów były bardzo trafne. Z Krakowa na początku lat dwudziestych wyjechali: Stefan Banach, Władysław Ślebodziński, Władysław Nikliborc i Stefan Kaczmarz, a na początku trzydziestych Otton i Stanisława Nikodymowie ${ }^{14}$. Zapewne trudny charakter prof. Zaremby był tylko jednym z powodów opuszczania ośrodka. W poszukiwaniu możliwości zatrudnienia w szkolnictwie wyższym w 1929 r. z Krakowa wyjechał także Stanisław Krystyn Zaremba, syn profesora; udał się do Wilna ${ }^{15}$.

Analizując sytuację w Wilnie, a także w ostatnim z polskich miast, w którym w okresie międzywojennym funkcjonował państwowy uniwersytet - w Poznaniu Łuzin uznał, że idą one drogą wytyczoną przez szkołę warszawską i lwowską (Łuzin 1983: 66). W tym wypadku nie do końca miał rację, patrzył na Poznań i Wilno, a szczególnie na drugie $\mathrm{z}$ wymienionych środowisk, przez pryzmat ich dobrej współpracy ze wspominanymi szkołami. Tymczasem w tych ośrodkach w połowie lat dwudziestych dominowały podobne preferencje przy wyborze podejmowanych problemów naukowych, jak w Krakowie. Jednak z czasem ta dobra współpraca ze szkołą warszawską i lwowską zaowocowała też w Wilnie i Poznaniu rozwojem podobnych pól badawczych (Przeniosło 2011a: 81-83, 85, 86).

Łuzin przyjeżdżał do Polski nie tylko sam, ale i ze swoimi uczniami, by mogli oni współpracować z członkami tutejszych szkół. Rosyjscy stypendyści bywali w Polsce również sami, szczególnie chętnie w Warszawie i Lwowie (Marczewski 1948: 30, 31; Kuratowski 1973: 68). Ścisła współpraca połączyła Aleksandrowa z Mazurkiewiczem, Urysona z Kuratowskim, Ninę Beri z innym warszawskim mate-

14 LPAO, UJK, f. 26, op. 5, spr. 819, k. 63; AAN, MWRiOP, sygn. 4593, k. 22, 23; Ważewski i Szarski 1964: 115, 116; Ślebodziński 1971: 18.

15 Litewskie Centralne Archiwum Państwowe w Wilnie, Uniwersytet Stefana Batorego, f. 175, ap. 6VIIB, b. 273, k. 2, 9; ap. 1IBb, b. 66, k. 44. 
matykiem Aleksandrem Rajchmanem. Aleksandrow zaprzyjaźnił się też z Banachem, Kuratowskim i dwoma jego kolegami z UW - Bronisławem Knasterem i Karolem Borsukiem (Aleksandrow 1963: 176, 1969: 61).

Dobra współpraca z warszawskimi i lwowskimi matematykami powodowała, że Łuzin rewanżował się dużą życzliwością w stosunku do nich. Często wykładał na europejskich uczelniach, np. na Sorbonie. Polscy matematycy przebywający tam wówczas wspominali, jak ułatwiał im kontakty w nowym dla nich środowisku, dotyczyło to np. profesora Politechniki Lwowskiej (PLw) Antoniego Łomnickiego, który był w Paryżu w 1930 r. ${ }^{16}$

Polscy matematycy starali się z kolei pomóc Łuzinowi w 1936 r., kiedy to w prasie, szczególnie w moskiewskiej „Prawdzie”, wysunięto przeciwko niemu dość absurdalny zarzut działania na szkodę ZSRR, m.in. poprzez publikacje w zagranicznych czasopismach (wcześniej nierzadko był za to nagradzany), wyjazdy i zbyt ścisłe kontakty z tamtejszymi uczonymi, szczególnie francuskimi. Wytykano mu także nierzetelność naukową. Chciano go pozbawić członkostwa w Rosyjskiej Akademii Nauk (Graham i Kantor 2009: 152-158). „Sprawa akademika Łuzina” odbiła się szerokim echem, a konsekwencje zarzutu działania na szkodę ZSRR mogły być niewątpliwie dalej idące. Polscy matematycy próbowali go wesprzeć. Szczególnie Sierpiński, poruszony alarmistycznymi listami od Łuzina, starał się zorganizować interwencje zagranicznych naukowców, ale w takiej formie, by mu pomogły, a nie zaszkodziły. List francuskich matematyków w tej sprawie, o który apelował Sierpiński, trafił np. na ręce ambasadora ZSRR w Paryżu. Podkreślano w nim, zresztą zgodnie z prawdą, jak znanym matematykiem jest Łuzin i jak to wpłynęło na pozycję rosyjskiej nauki (Duda 2004: 134-138). Co ciekawe, Łuzin nie stracił nawet miejsca w Akademii, wsparła go też bowiem spora grupa znanych rosyjskich akademików. Kontakty z polskimi i w ogóle zagranicznymi matematykami musiał jednak wówczas zerwać (Graham i Kantor 2009: 160, 161; Duda 2001: 42, 43). Reakcja Sierpińskiego na sprawę Łuzina nie została mu zapomniana w ZSRR. W $1948 \mathrm{r}$. tamtejsze władze nie pozwoliły na wyjazd radzieckiej delegacji na Zjazd Polskich Matematyków w Warszawie, który miał być połączony z jubileuszem Sierpińskiego. W liście z odmową nazwano go jednym z najbardziej reakcyjnych polskich matematyków i wytknięto, że w 1936 r. w prasie bronił Łuzina (Duda 2001: 45). Można się zastanawiać, czy Sierpiński $\mathrm{w}$ powojennej Polsce ucierpiał $\mathrm{z}$ powodu takich opinii, w istotny sposób na pewno nie, był bowiem zbyt wielką osobowością świata nauki.

W kampanię przeciwko Łuzinowi włączyła się część jego uczniów, szczególnie Paweł Aleksandrow (Graham i Kantor 2009: 160, 161). W związku z tymi wydarzeniami UW wycofał się ze zorganizowania wykładów, które Aleksandrow miał w 1936 r. wygłosić (Duda 2004: 135), choć prawdopodobnie sam Aleksandrow w zaistniałej sytuacji zrezygnowałby z wyjazdu do Polski. Współpracującym z nim polskim matematykom trudno było uwierzyć $\mathrm{w}$ to, że zaangażował się $\mathrm{w}$ atak na Łuzina, znali go bowiem jako człowieka bardzo życzliwego, który zresztą sam dużo

16 AAN, MWRiOP, sygn. 1646, k. 3; sygn. 4082, k. 152-158. 
przebywał za granicą i tam publikował. Wspomina go takim chociażby Kazimierz Kuratowski, który współpracował z nim od 1924 r., a na przykład w 1927 r. został przez niego zaproszony na kilka tygodni na Uniwersytet w Getyndze, gdzie wówczas wykładał, na jego seminarium przedstawiał swoje najnowsze wyniki naukowe (Kuratowski 1981: 82, 85). Rozważając przyczyny takiego zachowania wobec swego mistrza części członków jego „Luzitanii”, wydaje się, że bardziej istotne niż kwestie ideologiczne, były tu względy ambicjonalne. Znani już w świecie naukowym wychowankowie Łuzina czuli się niedoceniani przez niego i sygnalizowali to od lat, a atmosfera polityczna pchnęła ich do tak niegodziwego kroku. Nie jest też wykluczone, że częściowo powodował nimi strach przed tym, by im samym nie postawiono podobnych zarzutów.

Rosyjscy matematycy żyjący na emigracji oczywiście w 1936 r. nie zerwali kontaktów z Polakami. Wspomniany przy okazji jubileuszu „Fundamenta Mathematicae” prof. Jacob Tamarkin, który na stałe mieszkał w USA, był niezmiennie osobą bardzo życzliwą dla polskich naukowców. Chętnie gościł na Uniwersytecie Browna w Providence, gdzie pracował, przebywających tam Polaków. W roku akademickim 1931/1932 dzięki wsparciu Fundacji Rockefellera udał się do Providence na przykład młody warszawski matematyk Stanisław Saks. Po tej podróży w kolejnych latach opublikował kilka prac w czasopismach Amerykańskiego Towarzystwa Matematycznego, m.in. w bardzo znanym „Annales of Mathematics” $\left(1933\right.$, t. 34) ${ }^{17}$. Tamarkin współpracował i znał się z wieloma polskimi matematykami. Od 1935 r. był członkiem Towarzystwa Naukowego Warszawskiego (Skład 1938-1945: 9). Napisał też wiele przychylnych recenzji publikacji polskich matematyków, które ukazały się w „Bulletin of the American Mathematical Society”. Były one ważne nie tylko ze względu na prestiż czasopisma, ale i dlatego, że dotyczyły książek wydawanych w ramach serii „Monografie Matematyczne”, w której opublikowano syntezy badań prowadzonych przez polskich matematyków ${ }^{18}$. Tamarkin przygotował ocenę tomu pierwszego, który zawierał największe dzieło Stefana Banacha Théorie des opérations linéaires. Zrecenzował też kilka kolejnych - Téorie de l'intégrale (t. 2) Stanisława Saksa oraz Theory of the integral (t. 7, poszerzona angielska wersja poprzedniej książki), Trigonometrical series (t. 5) Antoniego Zygmunda oraz Theorie der Orthogonalreihen (t. 6) Stefana Kaczmarza i Hugona Steinhausa.

W recenzji książki Banacha Tamarkim podkreślał, iż autor po raz pierwszy przedstawił systematycznie teorię operacji liniowych w sposób bardzo ogólny, swoje rozważania przeprowadził bowiem dla możliwie szerokich klas przestrzeni abstrakcyjnych. Zwrócił również uwagę na to, że monografię wyróżnia wykorzystanie nowoczesnych metod teorii mnogości i teorii funkcji zmiennej rzeczywistej, które zapewniają elegancję i oryginalność rozumowań. Z kwestii

17 AAN, MWRiOP, sygn. 5510, k. 62, 88, 84.

18 Były to zazwyczaj prace obszerne (liczące ok. 300 stron) przedstawiające ówczesny stan opisywanych teorii. W okresie międzywojennym wydano 10 tomów „Monografii Matematycznych”. Redaktorami serii byli wspólnie matematycy warszawscy i lwowscy kierujący „Fundamenta Mathematicae” i „Studia Mathematica”. (Przeniosło 2011a: 162-165). 
szczegółowych jako zasługę autora wskazał odkrycie znaczącej roli twierdzenia o przedłużaniu funkcjonałów liniowych w analizie funkcjonalnej - słynne dziś twierdzenie Hahna-Banacha (Tamarkin 1934b: 13-16). Francuska praca Saksa zawierała nie tylko jego ustalenia, ale także za zgodą Dmitrija Mieńszowa pewne jeszcze jego niepublikowane wyniki dotyczące różniczkowalności funkcji zmiennej zespolonej. Była ona pierwszą pracą, która w traktowaniu całki wyszła poza przestrzenie euklidesowe, co podkreślił recenzent (Tamarkin 1934a: 16-18). W recenzji książki Zygmunda zwrócił m.in. uwagę, że jest ona najpełniejszym opracowaniem ówczesnej wiedzy o szeregach trygonometrycznych (Tamarkin 1936a: 95). W przypadku pracy Kaczmarza i Steinhausa również podkreślał, iż zawiera bardzo wyczerpujące przedstawienie teorii. Jako atut książki wskazał też to, że prezentuje dużo wyników po raz pierwszy ogłoszonych drukiem, a wiele dowodów twierdzeń zostało uproszczonych dzięki zastosowaniu metod analizy funkcjonalnej (Tamarkin 1938: 20, 21).

Polscy i rosyjscy matematycy zapraszali się nawzajem na kongresy i konferencje naukowe. Rosjanie gościli na Pierwszym Polskim Zjeździe Matematycznym we Lwowie w 1927 r. Na zjeździe chciano zgromadzić nie tylko polskich matematyków pracujących w kraju, ale i poza granicami oraz gości zagranicznych, szczególnie tych współpracujących z rodzimymi szkołami naukowymi. Wśród tych ostatnich było troje naukowców moskiewskich - Nikołaj N. Łuzin, Dmitrij E. Mieńszow i Nina Bari. Jeśli chodzi o przebieg zjazdu, to uroczyste otwarcie miało miejsce w auli UJK, a obrady odbywały się w salach miejscowej Politechniki. Komitet Organizacyjny pracował pod przewodnictwem profesora PLw Maksymiliana Hubera. Jego zastępcą był Hugo Steinhaus, kwestie programowe koordynował Stefan Banach. W sumie na zjazd przybyło 174 uczestników, wygłoszono 76 referatów w sześciu sekcjach i dwa wykłady plenarne. Spośród Rosjan Łuzin i Bari przedstawili swoje rozważania w sekcji teorii mnogości i funkcji zmiennej rzeczywistej, a Mieńszow w sekcji analizy (Księga 1929: 1-8). Kongres organizowało Polskie Towarzystwo Matematyczne, które zrzeszało również naukowców zagranicznych, po zjeździe zapisali się do niego Łuzin i Bari. Później także Mieńszow, Aleksandrow i Tamarkin (État 1929: 325, 328; État 1936: 192, 195, 197).

W 1929 r. w Warszawie zorganizowano Kongres Matematyków Krajów Słowiańskich. Rosjanie jako jedyni spośród przedstawicieli tych narodów na zjazd nie przyjechali, choć Łuzin i jego uczniowie nosili się z takim zamiarem ${ }^{19}$. Prawdopodobnie ich absencja i brak zgody na wyjazd z ZSRR wiązały się z nieprzychylną atmosferą, która narastała wówczas wokół najstarszego z moskiewskich profesorów Dmitrija Jegorowa, nauczyciela i bliskiego współpracownika Łuzina. Jegorow nie krył bowiem swojego przywiązania do religii prawosławnej i negatywnego stosunku do władz ZSRR. Podobne poglądy miał również Łuzin, choć nie demonstrował ich otwarcie. Obaj pozostawali też w bliskich stosunkach z niepokor-

19 Archiwum UJ, Spuścizna Tadeusza Banachiewicza (STB), sygn. DC 8, List Sierpińskiego do Banachiewicza z 11 IX 1929 r.; Zarankiewicz 1929: 127, 129. 
nym duchownym, inżynierem i filozofem, Pawłem A. Florenskim ${ }^{20}$. Po aresztowaniu Jegorowa w 1930 r. (zmarł rok później) rozpoczęły się ataki i na Łuzina (Graham i Kantor 2009: 126, 134-145). Były one inicjowane, podobnie jak wcześniej na Jegorowa, przez filozofa Ernesta Kolmana ${ }^{21}$. W rozważanym przypadku zakończyły się one w 1936 r. wspomnianą już „sprawą akademika Łuzina”. Przez cały ten okres, oprócz ponawianych ataków, Łuzinowi nie pozwalano na wyjazdy zagraniczne, nie mógł pojechać chociażby w 1931 r. do Wilna na Drugi Polski Zjazd Matematyczny (Rosjanie nie zjawili się w ogóle) czy też rok później na Międzynarodowy Kongres Matematyczny w Zurychu (Deuxième 1931: 170; Duda 2004: 131, 133).

W 1930 r. odbył się Pierwszy Kongres Matematyków Rosyjskich w Charkowie. Pojechali trzej matematycy z Warszawy: profesor Antoni Przeborski, który do $1918 \mathrm{r}$. pracował właśnie na Uniwersytecie w Charkowie ${ }^{22}$, oraz Jerzy Spława-Neyman i Aleksandr Rajchman. Zjazd zgromadził ponad 400 uczestników, w tym dużą grupę gości zagranicznych. Wygłoszono 11 referatów plenarnych i ponad 160 specjalistycznych w siedmiu sekcjach poświęconych różnym działom matematyki. Wykłady plenarne przedstawili m.in. bardzo znani goście zagraniczni: Paul Montel, Jacques Hadamard, Arnaud Denjoy, Elie Cartan i Wilhelm Blaschke. Zjazd był połączony z obchodami 50-lecia istnienia Towarzystwa Matematycznego w Charkowie (Pierwszy 1931: 75, 76).

$\mathrm{W}$ pierwszej połowie lat trzydziestych rosyjscy matematycy jako jedni z pierwszych na świecie zaczęli organizować obok zjazdów poświęconych całej matematyce także konferencje specjalistyczne. W 1934 r. w Moskwie odbyła się Konferencja Geometrii Różniczkowej. Był to pierwszy zjazd matematyków zajmujących się tą tematyką. Konferencja została zorganizowana $\mathrm{z}$ dużym rozmachem przez Instytut Matematyki i Mechaniki tamtejszego Uniwersytetu. Pomysłodawcą zjazdu był miejscowy profesor Benjamin Kagan kierujący Seminarium Rachunku Tensorów oraz współpracujący z nim holenderski uczony Jan Schouten. Organizatorzy pokrywali wszystkie koszty przejazdów na terenie ZSRR i pobytu gości zagranicznych w bardzo komfortowych hotelach oraz licznych dodatkowych atrakcji. Na konferencję zaproszono 11 naukowców spoza ZSRR, z Polski trzech - profesora Akademii Górniczej w Krakowie Antoniego Hoborskiego ${ }^{23}$ i jego ucznia Stanisława Gołąba oraz młodego warszawskiego matematyka Aleksandra Wundheilera. Wygłoszono 33 odczyty, skupiono się głównie na następujących polach zainteresowań: uogólnienie geometrii rzutowej na przestrzeni wielowymiarowej, zagadnienia topologiczno-różniczkowe geometrii, zastosowania geometrii różniczkowej. W czasie konferencji zrealizowano też ciekawą inicjatywę prof. Schoutena w postaci spot-

20 Aresztowany na kilka miesięcy w 1928 r., a następnie w 1933 r., stracony w 1937 r. (Graham i Kantor 2009: 140, 142, 145).

21 Archiwum UJ, STB, sygn. DC 8, List Sierpińskiego do Banachiewicza z 28 I 1934 r.; Graham i Kantor 2009: 134, 147, 148.

22 AAN, MWRiOP, sygn. 5186, k. 14.

23 Był prekursorem polskiej szkoły geometrii różniczkowej. AAN, MWRiOP, sygn. 2871, k. 79, 82; Przeniosło 2011a: 73. 
kań kilku małych grup naukowców interesujących się bardzo wyspecjalizowanymi zagadnieniami z zakresu geometrii różniczkowej. Chciano w ten sposób zapoczątkować dalszą współpracę i przynajmniej korespondencyjną wymianę najnowszych ustaleń, zaraz po ich oddaniu do druku. Uczestnicy uznali konferencję za bardzo udane przedsięwzięcie (Konferencja 1934: 88-90).

W 1935 r. w podobny sposób jak zjazd poświęcony geometrii różniczkowej Instytut Matematyki i Mechaniki Uniwersytetu Moskiewskiego zorganizował Międzynarodową Konferencję Topologiczną. Tym razem inicjatorem zjazdu był prof. Paweł Aleksandrow. Na konferencję przybyło 30 gości zagranicznych i podobna liczbę matematyków rosyjskich. Wśród obcokrajowców, naukowcy z Polski i USA stanowili najliczniejsze grupy, przyjechali także matematycy z Czechosłowacji, Danii, Francji, Holandii i Norwegii. Z Polski byli warszawscy matematycy: Wacław Sierpiński, Stefan Mazurkiewicz, Kazimierz Kuratowski, Karol Borsuk, Kazimierz Zarankiewicz oraz Juliusz Schauder ze Lwowa ${ }^{24}$. Przyjechał także Witold Hurewicz pracujący na Uniwersytecie w Amsterdamie, jeden z najbardziej znanych polskich topologów. W prezydium zjazdu znaleźli się przedstawiciele wszystkich wymienionych państw, w tym Wacław Sierpiński. Wygłoszono ponad 50 referatów w językach angielskim, francuskim, niemieckim i rosyjskim. Dotyczyły one głównie pięciu pól badawczych: wielomiany $n$-wymiarowe, zagadnienia topologiczne związane $\mathrm{z}$ teorią mnogości punktowych, mówili na ten temat m.in. Sierpiński, Kuratowski i Mazurkiewicz; twory o własnościach zbliżonych do wielościanów - Borsuk; topologia grup ciągłych, zagadnienia z pogranicza topologii i geometrii różniczkowej -Schauder (Zarankiewicz 1935: 114-116; Borsuk 1936: 134-137). Warto dodać, że we wszystkich wymienionych przypadkach podróży do ZSRR matematycy otrzymali bezpłatne lub ulgowe paszporty ${ }^{25}$. Polskie władze wspierały więc uczonych w wyjazdach do tego kraju, podobnie jak i do wielu innych państw, choć mogły takiej pomocy odmówić, co czasem się zdarzało ${ }^{26}$.

Polscy i rosyjscy matematycy zapraszali się też nawzajem do wygłoszenia wykładów na swoich uczelniach, niektórzy znaleźli na nich stałe zatrudnienie. Na UW np. w roku akademickim 1927/1928 gościł Łuzin (Sprawozdanie 1928: 14). W latach dwudziestych w Warszawie zamieszkał emigrant z ZSRR Jerzy Popróżenko, doktoryzował się na UW w 1930 r., zatrudnienie znalazł na tutejszej Politechnice (Przeniosło 2011a: 51, 95). Z kolei w 1935 r. młody warszawski matematyk Kazimierz Zarankiewicz wygłosił cykl wykładów na Uniwersytecie w Tomsku, pojechał tam na zaproszenie Stefana Bergmana, który wówczas pracował na tej uczelni ${ }^{27}$. Bergman pochodził z Częstochowy, ale całe dorosłe życie spędził poza krajem w różnych ośrodkach

24 Archiwum UW, Akta Pracownicze, sygn. K 4758, k. 5; sygn. K 5822, k. 2; AAN, MWRiOP, sygn. 1817 , k. 55; sygn. 5618, k. 189; sygn. 6801 , k. 61.

25 Zgodnie np. z uregulowaniami z 1930 r. opłata za ulgowy paszport uprawniający do jednorazowego wyjazdu za granicę wynosiła 20 zł, a do wielokrotnych podróży - 100 zł, pełen koszt był równy odpowiednio 100 zł i 250 zł. Dziennik Ustaw RP 1930, nr 7, poz. 57, s. 48-50.

26 AAN, MWRiOP, sygn. 2032, k. 57; sygn. 5618, k. 177; Przeniosło 2011a: 176, 197.

27 AAN, MWRiOP, sygn. 6801, k. 28, 57. 
naukowych, w ZSRR przebywał w latach 1934-1937, najpierw w Tomsku, później w Tbilisi (Skwarczyński 1981: 189-191). Podobną drogę życiową wybrał Celestyn Burstin, który urodził się w Tarnopolu, studiował we Lwowie i Wiedniu, w drugim z tych miast mieszkał również w latach dwudziestych, od 1929 r. przebywał w ZSSR, był profesorem Uniwersytetu w Mińsku (Mioduszewski 1998a: 161-164). W Tbilisi w 1936 r. z wykładami gościł inny warszawski matematyk Arnold Walfisz, został tam zatrudniony i pozostał na stałe (Arnold Walfisz 1964: 225).

Wyjazdy z wykładami do ZSRR, a szczególnie stałe tam zatrudnienie, mogło mieć oczywiście podłoże ideologiczne. W przypadku Burstina, Walfisza i Zarankiewicza tak postrzegał to znający ich warszawski matematyk - Zenon Waraszkiewicz. Przy czym pierwszego z nich uważał za bolszewika, drugiego za trockistę, a u Zarankiewicza widział raczej tylko lewicowe poglądy i pewną fascynację ZSRR, którą sam w pewnym stopniu podzielał. Docierały do niego też informacje, że we wspomniany atak na Łuzina mocno zaangażowany był Burstin. Wśród mających lewicowe poglądy Waraszkiewicz wymienia też innych warszawskich matematyków - Aleksandera Rajchmana, Adolfa Lindenbauma, Zygmunta Zalcwassera, Salomona Lubelskiego ${ }^{28}$. W przypadku dwóch pierwszych potwierdzają to również inne źródła. Spośród matematyków skrajnie lewicowe zapatrywania mieli także Leon Chwistek i Marceli Stark ze Lwowa. Rajchman, Lindenbaum i Stark działali w Komunistycznej Partii Polski (Przeniosło 2011a: 360-363). Interesujące jest, czy współpraca naukowa z Rosjanami mogła wpłynąć na ich zapatrywania polityczne. W przypadku Rajchmana (niewykluczone, że również Lindenbauma) kontakty chociażby z Aleksandrowem mogły spowodować radykalizację poglądów, ale lewicowe zapatrywania miał on już na początku lat dwudziestych ${ }^{29}$. Wpływ Aleksandrowa jest jednak widoczny chociażby w ich stosunku do sprawy Łuzina, obaj mieli bowiem publicznie mawiać: „żeby nie zapomnieć o tym, że Jegorow, Łuzin i Florenski, to »czarna sotnia«, która miała początek w uniwersyteckiej Moskwie pokolenie wcześniej”30.

W kontekście kontaktów z matematykami z ZSRR warto zwrócić też uwagę na poglądy polityczne Sierpińskiego, był on bowiem zwolennikiem Narodowej Demokracji. Można się zastanawiać, czy jego przyjaźń z Łuzinem, która przecież legła u podstaw współpracy polskich i rosyjskich matematyków w okresie międzywojennym, przetrwałaby, gdyby Łuzin po 1917 r. popierał nowe władze. Wydaje się, że raczej nie, choć Sierpiński miał tę cechę, że w przypadku osób, które znał i cenił, potrafił akceptować wiele faktów $\mathrm{z}$ ich życia zupełnie sprzecznych $\mathrm{z}$ jego poglądami politycznymi. Na przykład spora grupa jego uczniów, których wspierał, miała żydowskie pochodzenie ${ }^{31}$. Zaliczał się do nich też Rajchman, nawet mimo swoich lewicowych poglądów ${ }^{32}$.

28 Z. Waraszkiewicz, Dwie Warszawy. Pamiętnik, oprac. T. Grabiński, J. Mioduszewski, math. us.edu.pl, www.math.us.edu.pl/mioduszewski/dwiewarszawy4.doc [dostęp 15.06.2013].

29 Archiwum Uniwersytetu Adama Mickiewicza w Poznaniu (AUAM), Rektorat 1919-1939, sygn. 15/482, k. 6; Listy 1980: 27.

30 Z. Waraszkiewicz, op. cit.

31 AAN, MWRiOP, sygn. 5510, k. 33, 34; Przeniosło 2011a: 47, 131.

32 AUAM, Rektorat 1919-1939, sygn. 15/482, k. 6. 
Kontakty między polskimi i rosyjskimi matematykami w okresie międzywojennym trzeba uznać za wyjątkowo dobre. We wzajemnych relacjach nie brakowało życzliwości, rodziły się przyjaźnie. Cenili też swoje dokonania naukowe, tworzyły się zespoły ściśle współpracujących ze sobą osób. Niestety w 1936 r. za sprawą władz ZSRR kontakty te zostały zerwane.

\section{Scientific relations of Polish and Russian mathematicians in the interwar period}

This paper presents relations between Polish and Russian mathematicians in the interwar period, in particular, scientific cooperation, scientific trips and bilateral relations. In view of conducted inquiries, the connections are perceived as correct, considering relations between both countries. Russians printed numerous papers in Warsaw journal "Fundamenta Mathematicae", they also wrote to "Studia Mathematica" published in Lviv. They were interested in the condition of Polish mathematics, especially Nikołaj N. Łuzin, the Russian prominent scholar. In addition, they visited Polish universities as lecturers and scholarship holders and took part in the First Polish Mathematical Congress in Lviv in 1927. Later on, Poles participated in the First All-Union Congress of Mathematicians in Kharkov in 1930, the Conference on Differential Geometry in Moscow and the International Conference on Topology in 1934 and in 1935. Thanks to the cooperation with foreign mathematicians, both conferences were well prepared. Such specialist conferences were not frequently organized at that time, however, Russians were pioneers in this matter. Poles also went to USSR universities to deliver lectures; some people stayed there permanently. Polish and Russian mathematicians were kind and made new friends. They were proud of their scientific achievements. However, due to the USSR authorities, the relations were broken out in 1936. While writing this paper, archival materials were used, mainly from the Central Archives of Modern Records (Ministry of Religious Affairs and Public Education), Lviv and Vilnius archives and university archives. The printed source materials, especially collections of letters and various reports, were also significant. Diaries and memories of the interwar period turned out to be equally important.

Translated by Marta Antoniuk

\section{Научные контакты польских и советских математиков в Интербеллуме}

Целью статьи является представление контактов между польскими и советскими математиками в межвоенный период, особенно научного сотрудничества и связанных с ним научных путешествий. В свете проведенных исследований надо признать эти контакты исключительно успешными, учитывая отношения между обеими странами. Советские ученые опубликовали значительное число работ в варшавском журнале „Fundamenta Mathematicae”, а также время от времени во львовском „Studia Mathematica”. Ученые, a особенно самый известный среди них Николай Н. Лузин, интересовались состоянием польской математики. Они бывали в польских высших учебных заведениях как преподаватели и стипендиаты, участвовали в Первом польском математическом съезде во Львове в 1927 г. В свою очередь, поляки ездили в 1930 г. в Харьков на Всесоюзный съезд математиков, а в 1934 и в следующем году в Москву на Конференцию по тензорной дифференциальной геометрии, а также на Международную конференцию по топологии. Обе конференции были большими начинаниями, хорошо подготовленными, в сотрудничестве с иностранными математиками. В этот период организовалось не так уж много специализирован- 
ных конференций и советская сторона стала одним из пионеров в этом деле. Поляки также ездили с лекциями в советские ВУЗы, были и такие, кто остался там навсегда. Во взаимоотношениях польских и советских математиков присутствовала доброжелательность, рождалась дружба. Они ценили свои научные достижения, создавались команды тесно сотрудничающих друг с другом людей. Однако в 1936 г., вследствие действий властей СССР, эти контакты были оборваны. В работе над статьей я использовала архивные материалы, главным образом из Архива Актов Новых в Варшаве (фонд - Министерство Религиозных Конфессий и Публичного Просвещения), львовских и вильнюсских, а также вузовских архивов. Существенными оказались печатные источники, как собрания писем, так и разного рода отчеты. Как важные источники, использовались также мемуары и воспоминания межвоенного периода.

Перевод Агнешка Поспишыль

\section{Bibliografia}

Aleksandrow P. S., List do prof. K. Kuratowskiego, „Wiadomości Matematyczne” 1969, t. 12, z. 1, s. 59-61.

Aleksandrow P. S., O pewnych przejawach wspótpracy polskiej i radzieckiej szkoły matematycznej $w$ dziedzinie topologii i teorii mnogości, „Wiadomości Matematyczne” 1963, t. 6, z. 2, s. 175-180. Arnold Walfisz (1892-1962). A biographical note, „Acta Arithmetica” 1964, t. 10, z. 3, s. 225.

Borsuk K., Międzynarodowa Konferencja Topologiczna w Moskwie, „Wiadomości Matematyczne” 1936, t. 41, s. 134-137.

Deuxième Congrès des Mathématiciens Polonais. Wilno 1931, „Annales de la Société Polonaise de Mathématique" 1931, t. 10, s. 132-150.

Duda R., Jeszcze raz o sprawie akademika Łuzina, „Wiadomości Matematyczne” 2004, t. 40, s. $129-138$.

Duda R., Sprawa akademika Łuzina, „Wiadomości Matematyczne” 2001, t. 37, s. 27-46.

État de la Société Polonaise de Mathématique à la fin de l'année 1928, „Annales de la Société Polonaise de Mathématique" 1929, t. 8, s. 325-330.

État de la Société Polonaise de Mathématique à la fin de l'année 1936, „Annales de la Société Polonaise de Mathématique" 1936, t. 15, s. 192-198.

Graham L. i Kantor J.-M., Naming infinity. A true story of religious mysticism and mathematical creativity, Cambridge 2009.

Janiszewski Z., O potrzebach matematyki w Polsce, „Nauka Polska” 1918, t. 1, s. 11-18.

Konferencja Geometrii Różniczkowej w Moskwie, „Mathesis Polska” 1934, t. 9, nr 5-6, s. 88-90.

Księga pamiątkowa Pierwszego Polskiego Zjazdu Matematycznego. Lwów 7-10 IX 1927, Kraków 1929.

Kuratowski K., Notatki do autobiografii, Warszawa 1981.

Kuratowski K., Pięćdziesiąt tomów „Fundamenta Mathematicae”. Wspomnienia i uwagi, „Wiadomości Matematyczne” 1963, t. 7, z. 1, s. 9-17.

Kuratowski K., Pół wieku matematyki polskiej, Warszawa 1973.

Listy Wacława Sierpińskiego do Stanisława Ruziewicza, oprac. W. Więsław, „Wiadomości Matematyczne" 2004, t. 40, s. 139-167.

Listy Zygmunta Janiszewskiego, Preprint C-1 Instytutu Matematycznego Polskiej Akademii Nauk, oprac. S. Kolankowski, Warszawa 1980.

Łuzin N., List do Arnauda Denjoy z 1926 r., „Wiadomości Matematyczne” 1983, t. 25, z. 1, s. 65-68.

Marczewski E., Rozwój matematyki w Polsce, Kraków 1948.

Mioduszewski J., Celestyn Burstin (1888-1938). Członek Polskiego Towarzystwa Matematycznego, [w:] Matematycy polskiego pochodzenia na obczyźnie, red. S. Fudali, Szczecin 1998a, s. 161-164. 
Mioduszewski J., Okres moskiewski Wacława Sierpińskiego, [w:] Matematycy polskiego pochodzenia na obczyźnie, red. S. Fudali, Szczecin 1998b, s. 67-73.

Pierwszy Zjazd Matematyków Rosyjskich, „Mathesis Polska” 1931, t. 6, nr 3-4, s. 75, 76.

Poczet członków Akademii Umiejętności i Polskiej Akademii Umiejętności w latach 1872-2000, Kraków 2006.

Przeniosło M., „Fundamenta Mathematicae” - pierwsze polskie czasopismo matematyczne o waskiej specjalizacji (1920-1939), „Nauka” 2006, nr 2, s. 167-184.

Przeniosło M., Matematycy polscy w dwudziestoleciu międzywojennym, Kielce 2011a.

Przeniosło M., Powstanie i rozwój warszawskiej szkoły matematycznej, „Przegląd Historyczny” 2011b, nr 2, s. 205-220.

Przeniosło M., Twórcy lwowskiej szkoły matematycznej (1920-1939), „Dzieje Najnowsze” 2007, nr 2, s. 59-76.

Schinzel A., Wacław Sierpiński, Warszawa 1976.

Skład Towarzystwa Naukowego Warszawskiego w okresie od 24 XI 1937 do 6 I 1946, „Rocznik Towarzystwa Naukowego Warszawskiego" 1938-1945, t. 31-38, s. 5-23.

Skwarczyński M., Stefan Bergman (1895-1977), „Wiadomości Matematyczne” 1981, t. 23, z. 2, s. $189-191$.

Sobolew S. Ł., Przemówienie wygłoszone na uroczystości ku uczczeniu pamięci Stefana Banacha, „Wiadomości Matematyczne” 1961, t. 4, z. 3, s. 261-264.

Sprawozdanie z działalności Uniwersytetu Warszawskiego za rok akademicki 1927/1928, Warszawa 1928.

Ślebodziński W., Wspomnienia matematyka z lat 1903-1968, „Wiadomości Matematyczne” 1971, t. 12, z. 1, s. 17-31.

Tamarkin J. D. (rec.), Antoni Zygmund, Trygonometrical series, Warszawa-Lwów 1935, „Bulletin of the American Mathematical Society" 1936a, t. 42, s. 95, 96.

Tamarkin J. D. (rec.), Stanisław Saks, Théorie de l'intégrale, Warszawa 1933, „Bulletin of the American Mathematical Society" 1934a, t. 40, s. 16-18.

Tamarkin J. D. (rec.), Stefan Banach, Théorie des operations linéaires, Warszawa 1932, „Bulletin of the American Mathematical Society" 1934b, t. 40, s. 13-16.

Tamarkin J. D. (rec.), Stefan Kaczmarz, Hugo Steinhaus, Theorie der Orthogonalreihen, Warszawa-Lwów 1935, „Bulletin of the American Mathematical Society” 1938, t. 44, s. 20, 21

Tamarkin J. D., 25 volumes of „Fundamenta Mathematicae”, „Bulletin of the American Mathematical Society" 1936b, t. 42, s. 300.

Ważewski T. i Szarski J., Stanisław Zaremba, [w:] Studia z dziejów katedr Wydziału Matematyki, Fizyki, Chemii Uniwersytetu Jagiellońskiego, red. S. Gołąb, Kraków 1964, s. 102-117.

Zarankiewicz K., Kongres Matematyków Krajów Słowiańskich, „Mathesis Polska” 1929, t. 4, nr 7-8, s. 127-129.

Zarankiewicz K., Międzynarodowa Konferencja Topologiczna w Moskwie, „Mathesis Polska” 1935, t. 10, nr 5-6, s. 114-116.

Dr hab. Małgorzata Przeniosło - prof. Uniwersytetu Jana Kochanowskiego w Kielcach, pracownik Instytutu Edukacji Szkolnej. Zainteresowania badawcze: historia nauki, dzieje ziemiaństwa polskiego, dobroczynność i pomoc społeczna w XX wieku. 